\title{
Usefulness of Presepsin (Soluble CD14 Subtype) as a Diagnostic Marker of Sepsis in Egyptian Patients with Acute Myeloid Leukemia
}

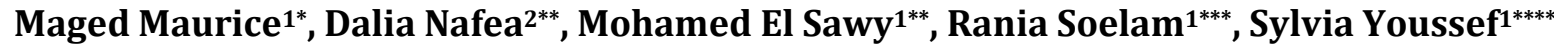 \\ ${ }^{1}$ Department of Clinical Pathology, Faculty of Medicine, Alexandria, Egypt \\ ${ }^{2}$ Department of Internal Medicine, Alexandria, Egypt \\ Email: dnafea@hotmail.com
}

Received 30 July 2014; revised 29 August 2014; accepted 28 September 2014

Copyright $@ 2014$ by authors and Scientific Research Publishing Inc.

This work is licensed under the Creative Commons Attribution International License (CC BY).

http://creativecommons.org/licenses/by/4.0/

(c) (i) Open Access

\section{Abstract}

Background: Systemic inflammatory response syndrome (SIRS) is a systemic inflammatory response to a variety of insults. Presepsin; the soluble CD14 subtype is a novel soluble CD14 molecule that is useful for diagnosing sepsis. It plays an important role in modulating the immune response to endotoxin in vitro and vivo. The aim: Of the study was to evaluate the usefulness of presepsin as a diagnostic marker of sepsis in acute leukemia. Methods: The current study was carried out on 40 adult patients with acute myeloid leukemia after receiving chemotherapy. 10 clinically normal individuals were included in the study to measure the level of presepsin. Results: This study was conducted on 50 individuals divided into 2 groups. Group I included 40 adult AML patients who fulfilled at least two of the diagnostic criteria for SIRS and Group II were 10 healthy adult persons as a control group. In Group I there were 11 patients (27.5\%) having SIRS, 8 (20\%) having sepsis, 9 $(22.5 \%)$ having severe sepsis and $12(30 \%)$ having septic shock. Data indicate that presepsin level was significantly higher in patients than control $P=0.017$. Our results showed that the level of presepsin has a significantly positive correlation to the degree of severity of sepsis with $P$ value 0.0001 . Using the ROC curve, we found that presepsin was more specific than CRP in detection of sepsis. Conclusion: sCD14-ST (presepsin) is a new important marker for diagnosis and prognosis of sepsis. Its level increases in the first six hours after the onset of sepsis. Our data demonstrated that the concentration of presepsin is specifically increased during sepsis and is directly proportional to the degree of sepsis. Regarding sensitivity and specificity of presepsin in the discrimination of sepsis patients from healthy controls, a high specificity but low sensitivity was reported by most of the studies.

${ }^{*}$ Professor; ${ }^{* *}$ Assisstant Professor; ${ }^{* * *}$ Lecturer; ${ }^{* * *}$ Resident.

How to cite this paper: Maurice, M., Nafea, D., El Sawy, M., Soelam, R. and Youssef, S. (2014) Usefulness of Presepsin (Soluble CD14 Subtype) as a Diagnostic Marker of Sepsis in Egyptian Patients with Acute Myeloid Leukemia. American Journal of Molecular Biology, 4, 169-176. http://dx.doi.org/10.4236/ajmb.2014.44019 


\section{Keywords}

\section{AML, SIRS, Presepsin, CRP}

\section{Introduction}

Acute leukemia is a clonal hematopoietic tissue that originates from hematopoietic stem or progenitor cells. It is characterized by the proliferation of blast cells in the bone marrow replacing the normal hematopoietic cells [1] [2].

Severe Neutropenia is defined as an absolute neutrophil count (ANC) $<500$ cells/cmm [3].

The risk of infection in the neutropenic patient is related to the virulence of the pathogen, the immunologic impairment of the host, and the disruption of skin and mucosal barriers [4].

Systemic inflammatory response syndrome (SIRS) is a systemic inflammatory response to a variety of insults (ischemia, inflammation, trauma). The response is manifested by two or more of the following conditions: temperature $>38^{\circ} \mathrm{C}$ or $<36^{\circ} \mathrm{C}$, heart rate $>90$ beats per minute, respiratory rate $>20$ breaths per minute or $\mathrm{PaCO}_{2}<$ $32 \mathrm{mmHg}$ and white blood cell count $>14.000$ cells/cmm or $<4.000$ cells/cmm [5] [6]. Sepsis is a SIRS in the presence of a confirmed or suspected infection. Severe sepsis is sepsis associated with organ dysfunction, hypoperfusion or hypotension. Septic shock is sepsis induced hypotension despite adequate fluid resuscitation. Presepsin; the soluble CD14 subtype is a novel soluble CD14 molecule that is useful for diagnosing sepsis [7]. CD14 is a glycosyl phosphatidyl inositol anchor type bone marrow glycoprotein. CD14 is an important cell surface receptor that binds lipopolysacharide [8]. It is expressed by cells of the myeloid lineage, B cells, liver parenchymal cells, gingival fibroblasts and microglial cells [9]-[13]. It plays an important role in modulating the immune response to endotoxin in vitro and vivo [14]-[17]. sCD14 \pm LPS complexes can activate cells which do not themselves express CD14 as endothelial cells leading to release of proinflammatory mediators. In addition, sCD14 may act as a shuttle molecule like LBP (lipopolysacharide binding protein) to transfer LPS to HDL (high density lipoprotein), thus neutralizing its toxic effects [18].

Presepsin is superior to other humoral factors in terms of its diagnostic power for sepsis [19] [20]. Measuring presepsin is also useful for evaluating the efficacy of treatment [21]-[23]. Significant correlations have been found between presepsin values and both acute physiology and chronic health evaluation II score (APACHE II score) and sequential organ failure assessment score (SOFA score). The insult of sepsis also seems capable of being inferred by making sequential observations. CRP and IL6 increase 1 - 2 days later and a slight time lapse develops between their rises and the changes in APACHE II.

The aim of the study was to evaluate the usefulness of presepsin as a diagnostic marker of sepsis in acute leukemia.

\section{Subjects and Methods}

The current study was carried out on 40 adult patients with acute myeloid leukemia (AML) after receiving chemotherapy. All patients were presented to the hematology department of Alexandria Main University Hospital during the period between July 2012 and March 2013.

The criteria used to include patients were the manifestations of sepsis in AML patients receiving chemotherapy. Patients with diabetes, chronic heart failure, HIV, TB, chronic inflammatory disease (Rheumatoid arthritis or systemic lupus erythematosis), on dialysis and surgical invasive procedures were excluded.

For normal control, 10 clinically and hematologically normal individuals of matched age and sex were included in the study to measure the level of presepsin. A written informed consent was obtained from all subjects before enrollment in the study.

\subsection{All Patients in the Present Study Were Subjected to the Following}

1) Full history taking and complete clinical examination.

2) Complete blood count: performed on 3 part differential automated cell counter Sysmex KX-21N (Sysmex, Kobe, Japan) [24].

3) ALT, AST, BUN, Serum creatinine, and uric acid: performed using DADE BEHRING Dimension RxL 
clinical chemistry auto-analyzer [25] [26].

4) Bone marrow aspirate: Using Klima needle from the sternum or iliac spine [27].

5) Immunophenotyping by flowcytometry for the diagnosis of AML [28]:

- Primary panel: CD2, CD7, CD10, CD13, CD14, CD33, CD34, CD45, CD19 and HLA-DR;

- Secondary panel: cyt CD22, cyt IgM, cyt-MPO.

6) Measurement of the level of C-reactive protein (CRP) [29].

7) Measurement of presepsin:

- Principle: It is based on a non-competitive chemiluminescent enzyme immunoassay (CLEIA) combined with MAGTRATION technology. The presepsin binds to (ALP) labelled polyclonal Abs and monoclonal Abs coated magnetic particles.

\subsection{Measurement Method}

1) $100 \mu \mathrm{l}$ whole blood were dispensed into the wells of the reagent cartridge.

2) To $25 \mu \mathrm{l}$ of the specimen, $25 \mu \mathrm{l}$ dilution solution, $50 \mu \mathrm{l}$ magnetic latex reagent $\& 50 \mu \mathrm{l}$ labelled $\mathrm{Ab}$ reagent were added and allowed to react at $37^{\circ} \mathrm{C}$ for $5 \mathrm{~min}$. Then washing was done three times with the wash solution provided.

3) $100 \mu \mathrm{l}$ luminescent substrates were added. The luminescence intensity generated was related to presepsin concentration in the sample.

4) The presepsin concentration was measured by comparison with the amount of luminescence of a calibration agent (CAL-1 \& CAL-2) that has been subjected to the same procedure as the sample.

5) The steps from (2) to (4) were automatically processed with an immunoassay analyzer (PATHFAST: Mitsubishi Chemical Medicine Corporation, Japan) [30].

\subsection{Statistical Analysis}

- The data were collected and entered into the personal computer. Statistical analysis was done using Statistical Package for Social Sciences (SPSS/version 20) software.

- The statistical tests used were as follow: Arithmatic mean, standard deviation, for categorized parameters Chi square test was used. While for two groups ANOVA-test was used for parametric data.

- ROC curve was done to determine the best cut off value of the marker to determine the highest value of sensitivity and specificity on this point.

- The level of significance was 0.05 .

\section{Results}

This study was conducted on 50 individuals divided into 2 groups: Group I included 40 adult AML patients who fulfilled at least two of the diagnostic criteria for SIRS and Group II were 10 healthy adult persons as a control group.

Group I included 27 male patients (67.5\%) and 13 female patients (32.5\%) whose ages ranged from 16 - 67 years with a mean \pm SD $44.82 \pm 33.4$ years. Group II included 5 males and 5 females whose ages ranged from 22 - 52 years with a mean \pm SD $33.4 \pm 10.98$ years.

In Group I there were 11 patients (27.5\%) having SIRS, 8 (20\%) having sepsis, 9 (22.5\%) having severe sepsis and $12(30 \%)$ having septic shock.

In the study we noticed that the presepsin levels in the 10 control healthy subjects were $<210 \mathrm{pg} / \mathrm{ml}$ while that of CRP levels were $<5 \mathrm{mg} / \mathrm{l}$. In the patients, the range was between $73.3-4550 \mathrm{pg} / \mathrm{ml}$ for the presepsin while that of the CRP was between $12.0-809 \mathrm{mg} / \mathrm{l}$. These data indicate that presepsin levels as well as the CRP levels were significantly higher in the patients than the control group $(\mathrm{P}=0.017, \mathrm{P}=0.004$ respectively) (See Table 1 ).

In normal subjects presepsin level ranged from $73-209 \mathrm{pg} / \mathrm{ml}$ with a mean \pm SD $132.5 \pm 50.6$, in SIRS patients presepsin level range from $73.3-254 \mathrm{pg} / \mathrm{ml}$ with a mean \pm SD $157.4 \pm 66.5$, in sepsis patients it was from $269-536 \mathrm{pg} / \mathrm{ml}$ with a mean \pm SD $440 \pm 106.4$, in severe sepsis patients the level ranged from $609-773 \mathrm{pg} / \mathrm{ml}$ with a mean \pm SD $693.3 \pm 58.9$ and in septic shock patients the level ranged from $861-4550 \mathrm{pg} / \mathrm{ml}$ with a mean \pm SD $1882.3 \pm 1076.4$. Our results showed that the level of presepsin has significantly increased in relation to the severity of sepsis with P value 0.0001 (See Table 2). 
Table 1. Comparison between patients and controls regarding presepsin and CRP levels.

\begin{tabular}{cccc|}
\hline & Patients & Control & Test P \\
\hline Presepsin $(\mathrm{pg} / \mathrm{ml})$ & & & 6.107 \\
\hline Range & $73.3-4550.0$ & $73.0-209.0$ & $0.017^{*}$ \\
Mean & 852.0 & 132.5 & \\
SD & 913.3 & 50.6 & 9.022 \\
\hline CRP (mg/l) & & & $0.004^{*}$ \\
\hline Range & $12.0-809.0$ & 2.3 & 1.2 \\
\hline Mean & 165.0 & 170.0 & \\
\hline
\end{tabular}

${ }^{*} \mathrm{P}<0.05$ is statistically significant.

Table 2. The relation between the level of presepsin and the type of sepsis.

\begin{tabular}{ccccccc}
\hline Presepsin (pg/ml) & Mean & SD & Min & Max & F & Sig \\
\hline Normal & 132.5 & 50.6 & 73.0 & 209.0 & 20.701 & $0.0001^{*}$ \\
SIRS & 157.4 & 66.5 & 73.3 & 254.0 & & \\
Sepsis & 440.0 & 106.4 & 269.0 & 536.0 & & \\
Severe sepsis & 693.3 & 58.9 & 609.0 & 773.0 & & \\
Septic shock & 1882.3 & 1076.4 & 861.0 & 4550.0 & & \\
\hline
\end{tabular}

${ }^{*} \mathrm{P}<0.05$ is statistically significant.

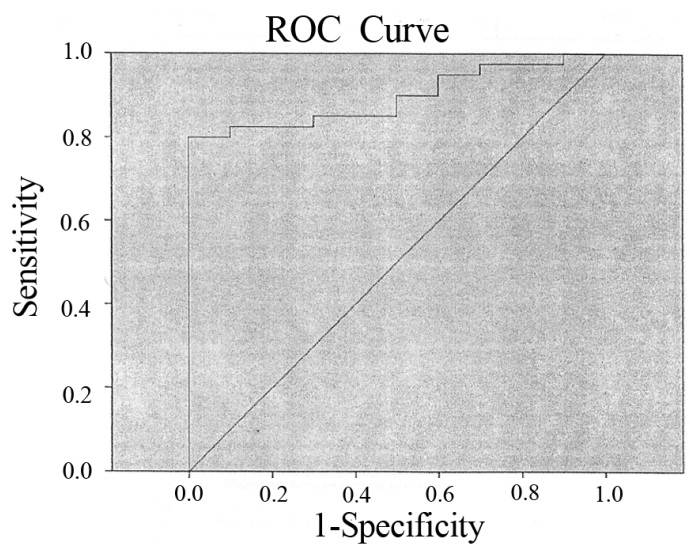

\begin{tabular}{cccc}
\hline Area & Cut off value & Sensitivity & Specificity \\
\hline 0.895 & 198.00 & 82.5 & $90 \%$ \\
\hline
\end{tabular}

Figure 1. ROC curve to determine the cut off value of presepsin.

Figure 1 the roc curve to determine the cut off value of presepsin in detection of patients and control.

The area under the curve (AUC) calculated from the ROC curve was 0.895 for presepsin and 0.707 for CRP. When the cut off value of presepsin was $198 \mathrm{pg} / \mathrm{ml}$, its clinical sensitivity was $82.5 \%$ and its clinical specificity was $90 \%$ suggesting its usefulness as a diagnostic marker of sepsis. While for CRP, when the cut off value was $96 \mathrm{mg} / \mathrm{l}$ its clinical sensitivity was $90 \%$ and its clinical specificity was $61 \%$. Thus we found that presepsin was more specific than CRP in the detection of sepsis.

Figure 2 and Figure 3 the ROC curves for the sepsis diagnostic markers (presepsin and CRP), in the SIRS, sepsis, severe sepsis and the septic shock groups.

When the cut of value of presepsin was $198 \mathrm{pg} / \mathrm{ml}$ (SIRS), its clinical sensitivity was 95\% and its clinical specificity was 55\%, when the cut of value of presepsin was $272 \mathrm{pg} / \mathrm{ml}$ (sepsis), its clinical sensitivity was $90 \%$ and 


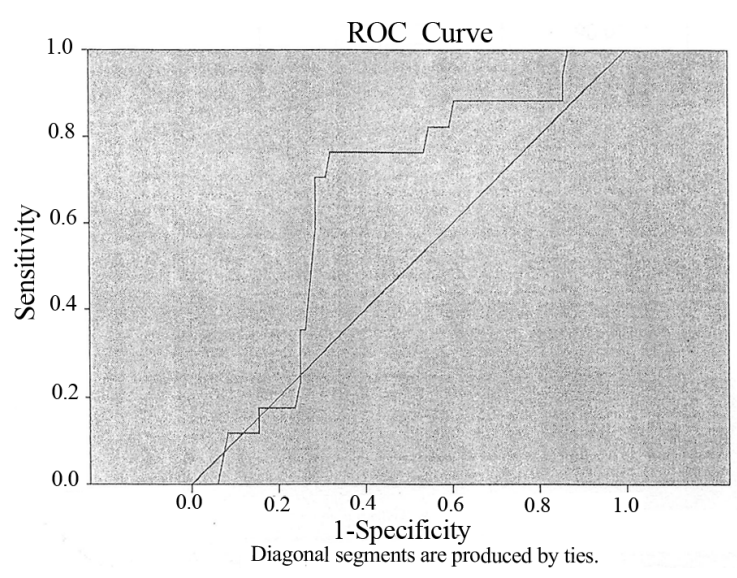

Figure 2. ROC curve to detect the level of presepsin in each type of sepsis.

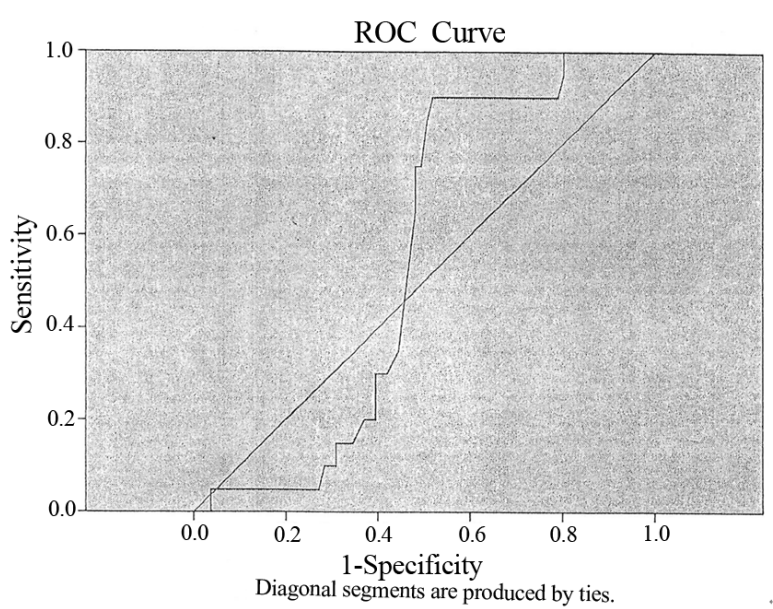

Figure 3. ROC curve to detect the level of CRP in each type of sepsis.

its clinical specificity was $70 \%$, when the cut of value of presepsin was $529 \mathrm{pg} / \mathrm{ml}$ (severe sepsis) its clinical sensitivity was $90 \%$ and its clinical specificity was $84 \%$, and when the cut of value of presepsin was $1043 \mathrm{pg} / \mathrm{ml}$ (septic shock), its clinical sensitivity was $85 \%$ and its clinical specificity was $100 \%$.

When the cut off value of CRP was $85 \mathrm{mg} / \mathrm{l}$ (SIRS), its clinical sensitivity was $51 \%$ and its clinical specificity was $66.7 \%$, when the cut off value of CRP was $123.5 \mathrm{mg} / \mathrm{l}$ (sepsis), its clinical sensitivity was $62 \%$ and its clinical specificity was $46.2 \%$. When the cut off value of CRP was $147.1 \mathrm{mg} / \mathrm{l}$ (severe sepsis), its clinical sensitivity was $42 \%$ and its clinical specificity was $15.4 \%$.

Better results were obtained with presepsin; so we can conclude that presepsin can be used as an indicator to the degree of severity of sepsis in comparison with CRP.

\section{Discussion}

The severity of sepsis varies considerably and early diagnosis is important to perform the specific treatment early. It is difficult to diagnose infection on the basis of the clinical findings alone as patients with non-infectious inflammation sometimes exhibit similar signs and symptoms.

C-reactive protein (CRP) has been used for many years as a biomarker of infection and inflammation although it has low specificity, it is commonly used to screen for early onset sepsis because its sensitivity is considered to be very high [31] [32].

Procalcitonin (PCT) has been proposed as a more specific [33] and has better prognostic marker than CRP, although its value has also been challenged [34]. 
sCD14-ST (presepsin) is a new important marker for diagnosis and prognosis of sepsis. Its level increases in the first six hours after the onset of sepsis [35].

The aim of our study was to test the potential of presepsin as an early biochemical marker to detect sepsis. In our data, a significant correlation was found between presepsin level and CRP $(P=0.001)$, similarly E. Spanuth, H. Ebelt et al. [30] conducted a study on 146 patients presenting with sepsis to assess the diagnostic and prognostic value of presepsin in emergency patients with early sepsis and found a significant correlation between presepsin and other markers including CRP $(\mathrm{P}<0.01)$.

We measured presepsin levels in healthy individuals, SIRS, sepsis, severe sepsis and septic shock patients and its level was $132.5 \pm 50.6 \mathrm{pg} / \mathrm{ml}, 157.4 \pm 66.5 \mathrm{pg} / \mathrm{ml}, 440 \pm 106.4 \mathrm{pg} / \mathrm{ml}, 693.3 \pm 58.9 \mathrm{pg} / \mathrm{ml}$ and $1882.3 \pm$ $1076.4 \mathrm{pg} / \mathrm{ml}$ respectively. Although we found a small elevation of presepsin in the SIRS group, the levels of presepsin in patients (sepsis, severe sepsis and septic shock) were significantly higher than those in patients with SIRS or the healthy control subjects $(\mathrm{P}=0.0001)$. These data demonstrated that the concentration of presepsin is specifically increased during sepsis and is directly proportional to the degree of sepsis. Our results were in agreement with that of Shigeatsu Endo et al. [36], who examined the significance of presepsin as a diagnostic marker of sepsis in a study including 46 sepsis patients. He found that presepsin values of the sepsis patients were found to be significantly higher than in the healthy subjects and in the SIRS who did not have source of infection ( $\mathrm{P}<0.0001)$. Spanuth et al. [30] in his study found that presepsin values differed significantly between patients with sepsis and severe sepsis or septic shock $(\mathrm{P}<0.0001)$.

In agreement with our study Tatsuyori Shozushima et al. [37] found that the patients with local infection or sepsis had significantly higher presepsin levels than the patients who did not have infection as a complication. In addition, the presepsin levels in SIRS that was not complicated by infection were significantly lower than in sepsis $(\mathrm{P}<0.05)$.

Regarding sensitivity and specificity of presepsin in the discrimination of sepsis patients from healthy controls, a high specificity but low sensitivity was reported by most of the studies.

These findings were confirmed by receiver operator characteristics (ROC) curves plotted for presepsin and CRP. The area under the curve for presepsin and CRP were 0.895 and 0.707 respectively.

In our study, presepsin had a sensitivity (82.5\%), lower than that of CRP (90\%) and a specificity (90\%) higher than that of CRP (61\%) at a cut-off value $198 \mathrm{pg} / \mathrm{ml}$ for presepsin and $96 \mathrm{mg} / \mathrm{l}$ for CRP.

Similar results were obtained by T. Nishida et al. [38] who found that presepsin was able to discriminate between patients with and without sepsis with a sensitivity and specificity of $92.9 \%$, and $83.3 \%$ respectively at a cut off value $647 \mathrm{pg} / \mathrm{ml}$ (AUC: 0.92 for presepsin and 0.83 for CRP).

Regarding sensitivity and specificity of presepsin in different types of sepsis, in our study, presepsin had a sensitivity (95\%) in SIRS, 90\% in sepsis and severe sepsis which was higher than its sensitivity in septic shock (85\%), and a specificity (55\%) in SIRS, (70\%) in sepsis, (84\%) in severe sepsis and (100\%) in septic shock. This means that the more the degree of severity of sepsis, the more is the level of presepsin and the more is its specificity in the diagnosis of sepsis. In our study, the results of presepsin were significantly higher than those of CRP, which had a lower sensitivity (51\% in SIRS, $62 \%$ in sepsis, $42 \%$ in severe sepsis and $44 \%$ in septic shock) and a lower specificity (66.7\% in SIRS, $46.2 \%$ in sepsis, 30.8\% in severe sepsis and $15.4 \%$ in septic shock). In general we found a higher specificity and sensitivity for presepsin than for CRP in different types of sepsis.

Similar results were reported in the study conducted by Tatsuyoni Shozushima et al. [37] who found that presepsin had a speicificty of $81 \%$ at high level compared to $78.5 \%$ at low level, but its sensitivity was more or less the same in different levels (80.3\% and $80.1 \%)$.

T. Nishida et al. [38] concluded that the ROC analysis at a cut-off value of $647 \mathrm{pg} / \mathrm{ml}$, presepsin may be able to discriminate between patients with and without sepsis with a sensitivity and specificity of $92.9 \%$ and $83.3 \%$ respectively. And the presepsin values were significantly higher in the patients with the more severe septic condition.

\section{Conclusion}

As a marker of sepsis, sCD14-ST (presepsin) is a good discriminator between healthy and septic conditions with evidence of infection. It is expected to be widely used in clinical settings near future.

\section{References}

[1] Lichtman, M.A. and Liesveld, J.L. (2001) Acute Myelogenous Leukemia. In: Beutler, E., Lichtman, M.A., Coller, B.S., 
Kipps, T.J. and Seligsohn, U., Eds., Williams Hematology, 6th Edition, McGraw-Hill Company, New York, St. Louis, 1074-1083.

[2] Gilliland, D.G. (2001) Hematologic Malignancies. Current Opinion in Hematology, 8, 189-191. http://dx.doi.org/10.1097/00062752-200107000-00001

[3] Freifeld, A.G., Bow, E.J., Sepkowitz, K.A., et al. (2011) Clinical Practice Guideline for the Use of Antimicrobial Agents in Neutropenic Patients with Cancer: 2010 Update by the Infectious Diseases Society of America. Clinical Infectious Diseases, 52, e56. http://dx.doi.org/10.1093/cid/cir073

[4] Viscoli, C., Varnier, O. and Machetti, M. (2005) Infections in Patients with Febrile Neutropenia: Epidemiology, Microbiology, and Risk Stratification. Clinical Infectious Diseases, 40, S240. http://dx.doi.org/10.1086/427329

[5] Bone, R.C., Balk, R.A., Cerra, F.B., Dellinger, R.P., Fein, A.M., Knaus, W.A., et al. (1992) Definitions for Sepsis and Organ Failure and Guidlines for the Use of Innovative Therapies in Sepsis. The ACCP/SCCM Consensus Conference Committee. American College of Chest Physicians/Society of Critical Care Medicine. Chest, 101, 1644-1655.

[6] Levy, M.M., Fink, M.P., Marshall, J.C., Abraham, E., Angus, B., Cook, D., et al. (2001) SCCM/ESICM/AGCP/ATS/ SIS International Sepsis Definitions Conference. Critical Care Medicine, 31, 1250-1256.

[7] Okamura, Y. and Yokoi, H. (2011) Development of a Point-of-Care Assay System for Measurement of Presepsin (sCD14ST). Clinica Chimica Acta, 412, 2157-2161.

[8] Wright, S.D., Ramos, R.A., Tobias, P.S., et al. (1990) CD14, a Receptor for Complexes of Lipopolysaccharide (LPS) and LPS Binding Protein. Science, 249, 1431-1433.

[9] Antal-Szalmas, P., Van Strijp, J.A.G., Weersink, A.J.L., Verhoef, J. and Van Kessel, K.P.M. (1997) Quantitation of Surface CD14 on Human Monocytes and Neutrophils. Journal of Leukocyte Biology, 61, 721-728.

[10] Liu, S., Khemlani, L.S., Shapiro, R.A., Johnson, M.L., Liu, K., Geller, D.A., Watkins, S.C., Goyert, S.M. and Billiar, T.R. (1998) Expression of CD14 by Hepatocytes: Upregulation by Cytokines during Endotoxemia. Infection and Immunity, 66, 5089-5098.

[11] Peterson, P.K., Gekker, G., Hu, S., Sheng, W.S., Anderson, W.R., Ulevitch, R.J., Tobias, P.S., Gustafson, K.V., Molitor, T.W. and Ghao, C.C. (1995) CD14 Receptor-Mediated Uptake of Nonopsonized Mycobacterium tuberculosis by Human Microglia. Infection and Immunity, 63, 1598-1602.

[12] Sugawara, S., Sugiyama, A., Nemoto, E., Rikiishi, H. and Takada, H. (1998) Heterogeneous Expression and Release of CD14 by Human Gingival Fibroblasts: Characterization and CD 14-Mediated Interleukin-8 Secretion in Response to Lipopolysaccharide. Infection and Immunity, 66, 3043-3049.

[13] Ziegler-Heitbrock, H.W.L., Pechumer, H., Petersmann, I., Durieux, J.J., Vita, N., Labeta, M.O. and Strobel, M. (1994) CD14 Is Expressed and Functional in Human B Cells. European Journal of Immunology, 24, 1937-1940. http://dx.doi.org/10.1002/eji.1830240835

[14] Leturcq, D.J., Moriarty, A.M., Talbott, G., et al. (1996) Antibodies against CD14 Protect Primates from EndotoxinInduced Shock. Journal of Clinical Investigation, 98, 1533-1538. http://dx.doi.org/10.1172/JCI118945

[15] Pugin, J., Ulevitch, R.J. and Tobias, P.S. (1995) Activation of Endothelial Cells by Endotoxin: Direct versus Indirect Pathways and the Role of GD 14. Progress in Clinical Biological Research, 392, 369-373.

[16] Schimke, S., Mathison, J., Morgiewicz, J., et al. (1998) Anti-CD14 mAb Treatment Provides Therapeutic Benefit after in Vivo Exposure to Endotoxin. Proceedings of the National Academy of Sciences of the United States of America, 95, 13875-13880. http://dx.doi.org/10.1073/pnas.95.23.13875

[17] Ulevitch, R.J., Dunn, D.L., Fink, M.P., et al. (1996) Endotoxin-Related Intracellular Pathways: Implications for Therapeutic Intervention. Shock, 6, 1-2. http://dx.doi.org/10.1097/00024382-199607000-00001

[18] Yu, B., Hailman, E. and Wright, S.D. (1997) Lipopolysaccharide Binding Protein and Soluble CDI4 Catalyze Exchange of Phospholipids. Journal of Clinical Investigation, 99, 315-324. http://dx.doi.org/10.1172/JCI119160

[19] Yaegashi, Y., Shirakawa, K., Sato, N., et al. (2005) Evaluation of a Newly Identified Soluble CD14 Subtype as a Marker for Sepsis. Journal of Infection and Chemotherapy, 11, 234-238. http://dx.doi.org/10.1007/s10156-005-0400-4

[20] Endo, S., Yaegashi, Y., Sato, N., et al. (2005) Usefulness of Soluble CD14 Subtype Which as Is a New Diagnostic Marker for Sepsis. Japanese Journal of Critical Care Endotoxemia, 9, 46-50. (In Japanese)

[21] Takahashi, G., Suzuki, Y., Kojika, M., et al. (2010) Evaluation of Responses to IVIG Therapy in Patients with Severe Sepsis and Septic Shock by Soluble CD14 Subtype Monitoring. Medical Postgraduates, 48, 19-24.

[22] Shozushima, T., Kojika, M., Takahashi, G., et al. (2010) Evaluation of Presepsin by a Point-of-Care Test (POC Test) Closely Reflect the Efficacy of Polymyxin-B Immobilized Fiber-Direct Hemoperfusion (PMX-DHP): A Case Report. The Journal of the Iwate Medical Association, 62, 411-416.

[23] Shozushima, T., Suzuki, Y., Kojika, M., et al. (2011) Soluble CDI4 Subtype Level Well Reflects the Results of Polymyxin-B Immobilized Fiber-Direct Hemoperfusion (PMX-DHP). Japanese Journal of Critical Care Endotoxemia, 15, 
116-121. (In Japanese)

[24] La Porta, A.D., Bowden, A.S. and Barr, S. (2004) Workflow Improvement and Impact of the New Beckman Coulter LII 1500 High Throughput Automated Hematology Workcell. Laboratory Hematology, 10, 95-101. http://dx.doi.org/10.1532/LH96.04022

[25] (2007) Beckman Coulter Synchron Clinical System Chemistry Information Manual.

[26] Stevens, L.A. and Levey, A.S. (2005) Measurement of Kidney Function. In: Singh, A.K., Ed., Medical Clinics of North America, W.B. Saunders, Philadelphia, 457.

[27] Islam, A. (1991) New Sternal Puncture Needle. Journal of Clinical Pathology, 44, 690-691.

[28] Michels, S.D., McKenna, R.W., Arthur, D.C. and Brunning, R.D. (1985) Therapy-Related Acute Myeloid Leukemia and Myelodysplastic Syndrome: A Clinical and Morphologic Study of 65 Cases. Blood, 65, 1364-1372.

[29] Roberts, W.L., Moulton, L. and Law, T.C. (2001) Evaluation of Nine Automated High-Sensitivity C-Reactive Protein Methods: Implications for Clinical and Epidemiological Applications. Part 2. Clinical Chemistry, 47, 418-425.

[30] Spanuth, E., Ebelt, H., Ivandic, B. and Werdan, K. (2011) Diagnostic and Prognostic Value of Presepsin (Soluble CD14 Subtype) in Emergency Patients with Early Sepsis Using the New Assay PATHFAST Presepsin. Proceedings of 21st International Congress of Clinical Chemistry and Laboratory Medicine, IFCC-WorldLab-EuroMedLab, Berlin, 15-19 May 2011.

[31] Povoa, P., Coelho, L., Almeida, E., Fernandes, A., Mealha, R., Moreira, P. and Sabino, H. (2005) C-Reactive Protein as a Marker of Infection in Critically Ill Patients. Clinical Microbiology and Infection, 11, 101-108. http://dx.doi.org/10.1111/j.1469-0691.2004.01044.x

[32] Hofer, N., Zacharias, B., Muller, W. and Resch, B. (2012) An Update on the Use of C-Reactive Protein in Early-Onset Neonatal Sepsis: Current Insights and New Tasks. Neonatology, 102, 25-36. http://dx.doi.org/10.1159/000336629

[33] Nakamura, A., Wada, H., Ikejiri, M., Hatada, T., Sakurai, H., Matsushima, Y., Nishioka, J., Maruyama, K., Isaji, S., Takeda, T. and Nobori, T. (2009) Efficacy of Procalcitonin in the Early Diagnosis of Bacterial Infections in a Critical Care Unit. Shock, 3l, 587-592. http://dx.doi.org/10.1097/SHK.0b013e31819716fa

[34] Tang, B.M.P., Eslick, G.D., Craig, S.C. and McLean, A.S. (2007) Accuracy of Procalcitonin for Sepsis Diagnosis in Critically Ill Patients: Systematic Review and Meta-Analysis. The Lancet Infectious Diseases, 7, 210-217. http://dx.doi.org/10.1016/S1473-3099(07)70052-X

[35] Yaegashi, Y., Sato, N., Suzuki, Y., Kojika, M., Imai, S., Takahashi, G., Miyata, M. and Endo, S. (2005) Evaluation of a Newly Identified Soluble CDI4 Subtype as a Marker for Sepsis. Journal of Infection and Chemotherapy, 11, $234-238$. http://dx.doi.org/10.1007/s10156-005-0400-4

[36] Endo, S., Takahashi, G., Shozushima, T., Matsumoto, N., Kojika, M., Suzuki, Y. and Inoue, Y. (2012) Usefulness of Presepsin (Soluble CD14 Subtype) as a Diagnostic Marker for Sepsis. Journal of Japanese Association for Acute Medicine, 23, 27-38.

[37] Shozushima, T., Takahashi, G., Matsumoto, N., Kojika, M., Okamura, Y. and Endo, S. (2011) Usefulness of Presepsin (sCD14-ST) Measurements as a Marker for the Diagnosis and Severity of Sepsis That Satisfied Diagnostic Criteria of Systemic Inflammatory Response Syndrome. Journal of Infection and Chemotherapy, 17, 764-769. http://dx.doi.org/10.1007/s10156-011-0254-X

[38] Nishida, T., Ishikura, H., Murai, A., Irie, Y., Yuge, R., Kamitani, T. and Endo, S. (2012) Assessment of the Usefulness of Presepsin (Soluble CD14 Subtype) in Septic Patients. Critical Care, 16, 32. 
Scientific Research Publishing (SCIRP) is one of the largest Open Access journal publishers. It is currently publishing more than 200 open access, online, peer-reviewed journals covering a wide range of academic disciplines. SCIRP serves the worldwide academic communities and contributes to the progress and application of science with its publication.

Other selected journals from SCIRP are listed as below. Submit your manuscript to us via either submit@scirp.org or Online Submission Portal.
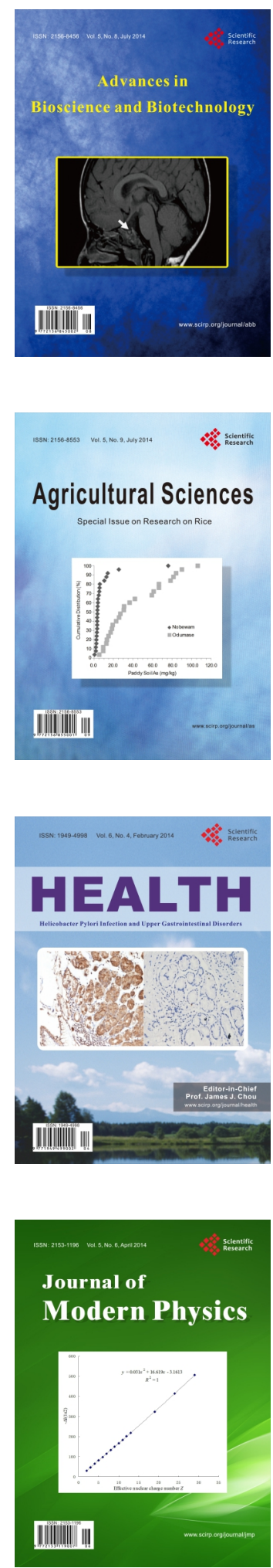
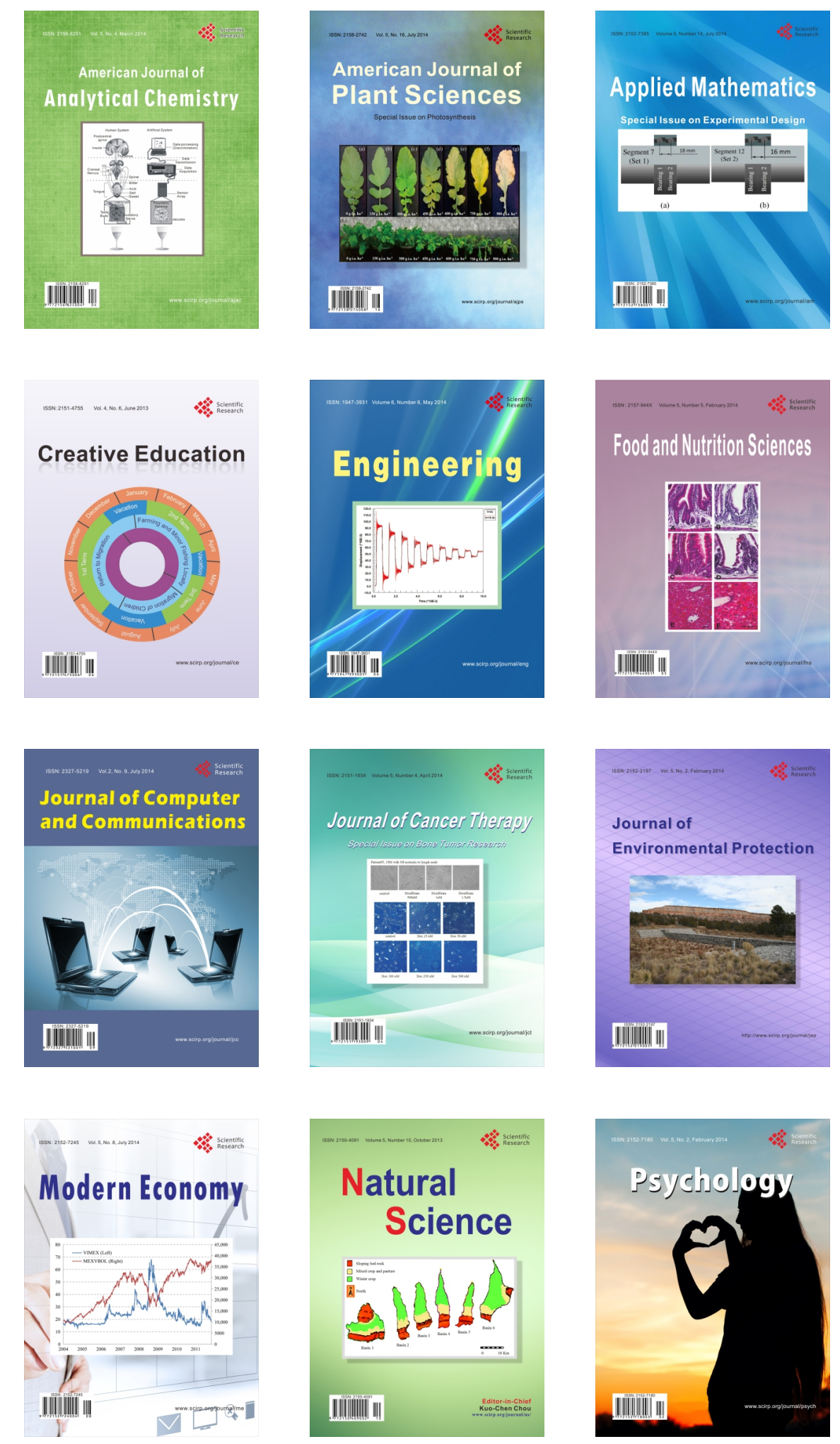